\title{
Effect of Nano Silica on Geotechnical Properties of Clayey Soil
}

\author{
Dhruva Kant Verma ${ }^{1}$, Dr. U. K. Maheshwari ${ }^{2}$ \\ ${ }^{1}$ Department of Civil Engineering, Bansal Institute of Engineering \& Technology, Lucknow, U.P., India \\ ${ }^{2}$ Department of Civil Engineering, KNIT, Sultanpur, U.P., India
}

\begin{abstract}
As the demand for land development is increasing, the soil improvement techniques are generally used to convert land on which construction is difficult. Structures constructed on clayey soils encounter many engineering problems such as bearing capacity settlement. Stabilization techniques are adopted to enhance the soil behavior and performance. Stabilization using many chemical additives such as cement, lime, bitumen and fly ash has been practice to improve soil properties for many years; Nano-chemicals are nanotechnology based products which can provide solutions to moisture and bonding issues for pavements construction. Addition of Nano-particles as an external factor to soil will result in soil manipulation at atomic or molecular level and it influences the strength, permeability indices and resistance properties of soil. Nanotechnology is a reformed mode which can address the rising concern of poor quality roads. There are various types of Nano materials such as $\mathrm{Nano}$ silica $\left(\mathrm{SiO}_{2}\right)$, Nano Titanium oxide $\left(\mathrm{TiO}_{2}\right)$ etc. are available. The Nano silica is mixed with soil samples $(C I)$ in varying proportions of $(0.0 \%, 0.25 \%, 0.50 \%, 0.75 \%$ and $1.0 \%)$ to study the geotechnical properties of soil. The results showed that UCS and CBR characteristics of soils get increases with increasing the percentages upto 0.75 $\%$ of $\mathrm{Nano}_{\mathrm{SiO}}$ and afterwards shows a gradual decrease.
\end{abstract}

Keywords: Nano Silica ( $\left.\mathrm{SiO}_{2}\right)$, clayey soils, California Bearing Ratio (CBR), unconfined shear strength (UCS).

\section{Introduction}

Structures constructed on clayey soils are more prone towards failure due to low strength, bearing capacity and settlement values which can be controlled and enhanced by suitably treating this by various additives such as cement, lime, bitumen, fly ash, Nano-material's etc. Soil stabilization is one of the oldest ground improvement techniques for improving the engineering properties of weak soils by reducing the permeability, compressibility and increasing shear strength and bearing capacity. Also, it is used to reduce the construction cost by making best use of the locally available materials. Further, soil stabilization is used to improve the properties of weak natural soils for the construction of highways and airfields by controlling the grading of soil and aggregate used in different pavement layers. The soil stabilization is done using either mechanical or additive method as per the requirement. In the recent days, as per the literature available Nano-particles are used as an additive to the soil. In this study Nano silica (Nonmaterial) used as additive with virgin soil. Nano silica is added with various percentages to clay samples. The soil sample used in the study is collected from Vrindavan Yojna lucknow. On the basis of experimental results, soil sample is classified as clayey soil with intermediate plasticity (CI) as per (BIS 1498-1970). Nano-silica was added to clay in varying proportions of $0.25 \%, 0.50 \%, 0.75 \%$, and $1.0 \%$ and its effect on the geotechnical properties are studied.

\section{Literature Review}

1. S. Babu \& S. Joseph (2015) to study the effect of various Nano materials (Nano Titanium Dioxide and Nano Fly ash) on the properties of soft soil. The Nanomater ial is mixed with soft soil at various percentages $(0 \%, 0.5 \%, 1 \%, 1.5 \%$ and $2 \%$ ). The optimum percentage of Nano materials is determined. The consolidation settlement behavior and CBR value was studied at the optimum percentage of Nano materials.

2. Priyadharshini and Arumairaj (2015) studied the effect of Nano-material's on the bearing capacity of soft soil and concluded. It has been observed that increase in Nano clay content increases the Atterberg's limits. Increase in Nano$\mathrm{MgO}$ and Nano-Alumina results in decrease in Atterberg's limits. The increase in Atterberg's limits is due to the higher specific surface area of nanoparticles encompassing large amount of water to the outer surface. With the increase in the percentage of Nano clay and Nano-Alumina, the optimum moisture content increases. With increase in Nano-MgO, optimum moisture content decreases. The presence of Nanopores causes water accumulation in these pores, resulting in increase of optimum moisture content. Soft clay attains the $\mathrm{OMC}$ at lower energy as the Nano-MgO content increases. With the increase in the percentage of Nano-clay and Nano Alumina, the maximum dry density decreases. The maximum dry density increases, with the increase in Nano $\mathrm{MgO}$ content. Increase in moisture content decreases cementing property of soil and decreases dry density. The unconfined compressive strength increases up to $48 \%$ for $1 \%$ nanoclay, $41 \%$ for $0.3 \%$ Nano-MgO and $43 \%$ for $0.75 \%$ of Nano-Alumina. The strength increase is due to thixotropic behavior of the Nano particles. The consolidation settlement behavior is reduced upto53\% for optimum dosage of Nano clay, $57 \%$ for optimum dosage of Nano-MgO and $54 \%$ for optimum dosage of Nano-Alumina. Thus Nano-MgO reduces the consolidation settlement when compared to the other two materials. The load carrying capacity of the footing for soft clay with optimum dosage of Nano-material's is increases up to $45.53 \%$ for Nano clay, $61.70 \%$ for Nano- $\mathrm{MgO}$ and $55.32 \%$ for $\mathrm{Nano}_{-} \mathrm{Al}_{2} \mathrm{O}_{3}$. Thus Nano-MgO shows an

\section{Volume 6 Issue 12, December 2017}




\section{International Journal of Science and Research (IJSR) \\ ISSN (Online): 2319-7064}

Index Copernicus Value (2015): 78.96 | Impact Factor (2015): 6.391

improved result in reducing the settlement and improving the load carrying capacity compared to the other two materials.

\section{Materials}

\section{Soil sample}

The clay soil sample which is collected from Vrindavan Yojna, Lucknow is tested in laboratory to determined the index and strength properties of soils and the following characteristics of selected soil have been summarized below in Table: 1

Table 1: Soil characteristics of the Selected Soil

\begin{tabular}{|c|c|}
\hline Physical Properties & Values \\
\hline Specific gravity & 2.696 \\
\hline Gravel (\%) & 0.00 \\
\hline Sand size (\%) & 34.13 \\
\hline Silt (\%) & 15.85 \\
\hline Clay (\%) & 50.02 \\
\hline Liquid limit (\%) & 41.10 \\
\hline Plastic limit (\%) & 22.22 \\
\hline Plasticity Index (\%) & 18.88 \\
\hline MDD (g/cc) & 1.79 \\
\hline OMC (\%) & 15.25 \\
\hline Soil Classification & CI (Clay with Intermediate Plasticity) \\
\hline Unconfined Shear & 59.33 \\
Strength (KPa) & 3.86 \\
\hline CBR (\%) & \\
\hline \multicolumn{2}{|c|}{} \\
\hline
\end{tabular}

Nano-Silica (Nano-material)

Nano Silica has been obtained from the standard manufacturing company situated at Delhi. The physical, thermal \& chemical properties of $\mathrm{Nano}_{\mathrm{SiO}}$ are given below:

\section{Physical Properties}

Silicon dioxide Nano-particles appear in the form of a white powder. The physical properties of $\mathrm{Nano}_{\mathrm{SiO}}$ are as follows:

1. The density of the Nano silica is $2.4 \mathrm{~g} / \mathrm{cm}^{2}$.

2. The molar mass of Nano silica is $56.96 \mathrm{~g} / \mathrm{mol}$.

\section{Thermal Properties}

The thermal properties of silicon dioxide Nano-particles are given below:

1) The boiling point of silicon dioxide Nano-particles is $1600{ }^{\circ} \mathrm{C}$.

2) The melting point of silicon dioxide Nano-particles is $2230{ }^{\circ} \mathrm{C}$.

\section{Chemical Properties}

The chemical properties of Nano silica particles are given in Table: 2 below:

Table 2: Chemical composition of Nano silica

\begin{tabular}{|c|c|}
\hline \multicolumn{2}{|c|}{ Chemical Composition } \\
\hline Element & Content (\%) \\
\hline Silicon & 46.83 \\
\hline Oxygen & 53.33 \\
\hline
\end{tabular}

\section{Experimental data \& analysis for soil added with Nano silica}

Experimental data and analysis has been done to determine the behavior of soil added with various proportions of Nano silica. The experimental data are obtained in laboratory as per standards prescribed by respective IS codes. The data has been collected for physical properties i.e. OMC, MDD, UCS and CBR. The various characteristics of selected CI soil affected by addition of Nano Silica in five different proportions i.e. $0,0.25,0.50,0.75$ and $1.0 \%$ by weight of soil.

\subsection{Compaction Characteristics}

4.1.1. Effect of Nano Silica on optimum moisture content (OMC) with varying percent



4.1.2. Effect of Nano Silica on Maximum dry density (MDD) with varying percent

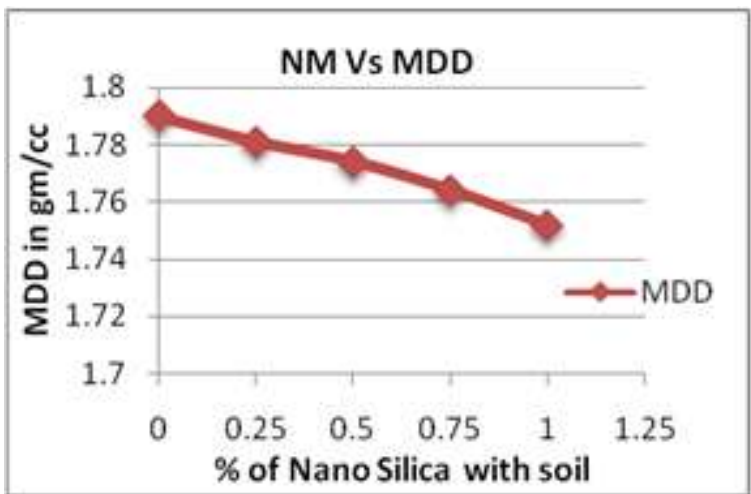

4.2 Unconfined shear strength (UCS)

\subsubsection{Effect of Nano silica on UCS with varying percent}

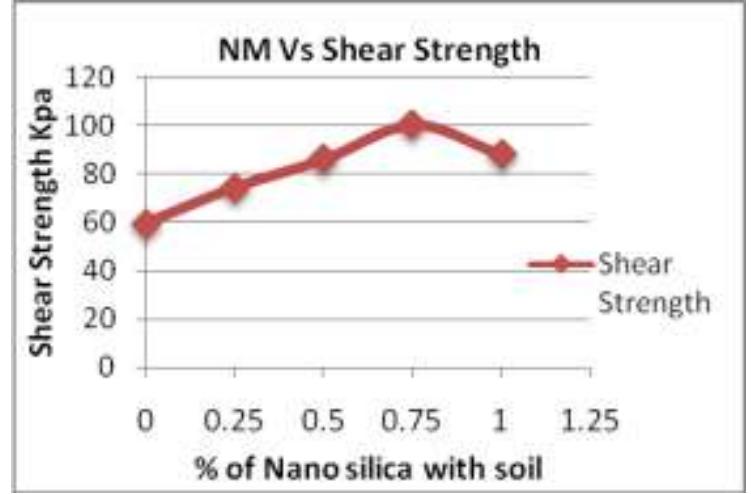

Volume 6 Issue 12, December 2017

www.ijsr.net

Licensed Under Creative Commons Attribution CC BY 


\subsection{California Bearing Ratio (CBR)}

\subsubsection{Effect of Nano Silica on CBR with varying percent}

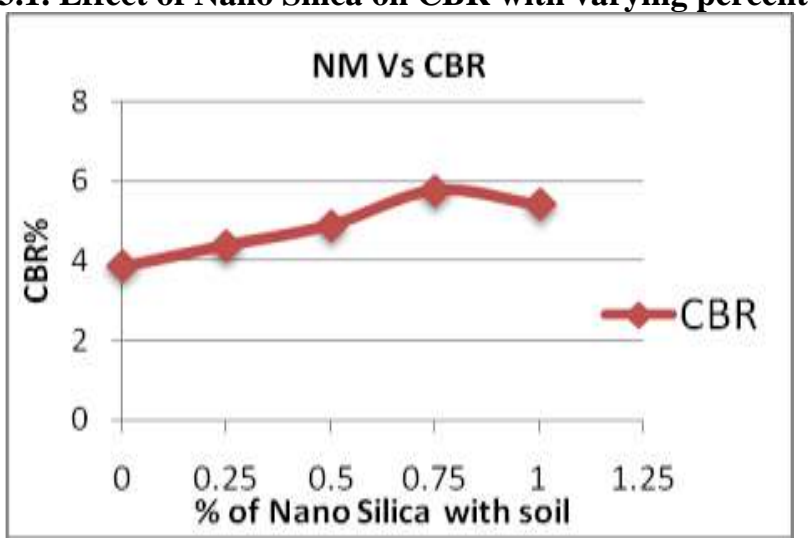

\subsection{Conclusions}

1) The soil chosen in the present thesis is of clay with intermediate plasticity i.e. CI soil having specific gravity, liquid limit, plastic limit, plasticity index, OMC, MDD, unconfined shear strength and CBR as 2.696,42.10,22.22, $18.88, \quad 15.25 \%, \quad 1.790 \mathrm{~g} / \mathrm{cc}, 59.33 \mathrm{kPa}$ and 3.86 respectively.

2) The OMC increases from $15.25 \%$ for selected soil to $18.72 \%$ for soil added with $1 \%$ Nano $\mathrm{SiO} 2$. The increasing trend is seen for the whole selected test range.

3) The MDD decreases continuously for the whole selected test. The decrease in MDD is maximum at $1 \% \mathrm{Nano} \mathrm{SiO} 2$ added i.e. $1.752 \mathrm{~g} / \mathrm{cc}$ with respect to $1.79 \mathrm{~g} / \mathrm{cc}$ for the selected soil.

4) The Unconfined Shear strength of soil added with Nano $\mathrm{SiO} 2$ shows that it first increases to a maximum value for $0.75 \%$ of Nano $\mathrm{SiO} 2$ and afterwards shows a gradual decrease. The maximum value is obtained at $0.75 \%$ addition i.e. $100.27 \mathrm{kPa}$ i.e. $69 \%$ higher than the for virgin soil i.e. $59.33 \mathrm{kPa}$.

5) The CBR first increases to a maximum value for $0.75 \%$ of Nano $\mathrm{SiO} 2$ and afterwards show a gradual decrease. However the values obtained are always higher compared to virgin soil. The maximum value of CBR obtained is at $0.75 \%$ addition of Nano $\mathrm{SiO} 2$ is approximately $49.22 \%$ higher than the CBR value obtained for virgin soil.

\section{References}

[1] Faheem.U (2008), “Clays Nano clays and Montmorilloniteminerials", J.Metalurgical and Materials Transactions., 113(12), 2805-2813.

[2] Taha, M.r., and Taha, O.M (2012), "Influence of Nano -material on the Expansive and Shrinkage Soil Behavior”. J.nanopart.research., springer, 90(5), 1 - 13.

[3] .Majeeed,Z.H and Taha,M.R.(2012), "Effect of Nano materials Treatment on Geotechnical properties of Penang soft soil". Journal of Asian Scientific Research.

[4] Sayad Hessam Bahmani and bujang B.K Huat (2014), "Stabilization of Residual Soil Using Silica Nanoparticles and Cement" Construction and building materials 64 350-359.
[5] Ali Akbar Firoozi (2014), "Assessment of Nanozeolite on soil propertiers" Australian journal of Basic and Applied Science,8(19) Special.

[6] Zaid Hameed Majeed and MohdRaihanTaha (2014), "Stabilization of Soil Using Nanomaterial's" Research journal of Applied Science, Engineering and Technology 8(4):503-509.

[7] R. Priyadharshini and P.D.Arumairaj (2015), "Improvement of Bearing Capacity of Soft Clay using Nanomaterial's" International Journal of Scientific Research Volumn:4,Issue:6,June.

[8] P. Hareesh and R. Vinothkumar (2016), "Assessment of nano materials on Geotechnical properties of Clayey soils" International Conference on Engineering Innovations and Solutions (ICEIS - 2016).

\section{Author Profile}

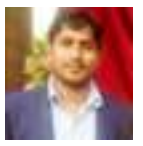

Dhruva Kant Verma received the B.Tech.(Civil Engineering) degree from SSPEM, Lucknow, U.P., India and M.Tech. degree in Geotechnical Engineering from KNIT, Sultanpur, U.P., India in 2012 and 2017, respectively. 